\title{
Australian farms and the separation of land and water titles: a research agenda
}

\author{
E. F. Smith \\ The University of Sydney, Australia
}

\begin{abstract}
Legislative changes separating water access title from land title potentially have the capacity to redefine the property relationships within Australian farm enterprises. Such changes might also initiate a set of unprecedented changes as to how farm owners organise their agricultural businesses, and manage their farm assets. Landowners now have access to a range of opportunities when managing two of the primary assets that contribute to agricultural production previously unavailable to them when water was associated with land titles. To recognise these new legal relationships, a plethora of administrative and institutional changes have been implemented which impact upon water ownership behaviours and farmers' attitudes toward water ownership more generally. To better understand the ways in which agricultural producers integrate, negotiate or resist these new governance structures for water alongside other drivers of change, research should be developed that constructs the farm as the unit of analysis; such an approach responds to calls from rural researchers to consider the family farm as an enduring form of social organisation that has the capacity to adapt to the modern world.

Keywords: property rights for water, farm adjustment, family farming, Australian water reform.
\end{abstract}

\section{Introduction}

Farm adjustment is an ongoing process as farmers continually adapt their lives and agricultural enterprises to their changing social, political, economic, and environmental contexts. Pressures from each of these contexts have contributed toward significant changes made to the ways in which Australia's water resources are managed, including fundamental changes to the nature of water 
rights. These changes had great significance for Australian farmers operating within irrigation districts when a market for the trade of water entitlements was introduced. More recently, though, within irrigation districts, land ownership and water access ownership have been formally separated, or unbundled. This process has removed the historical tie between land title and water access ownership, allowed farmers to buy and sell their water rights independently from their land holdings, and made it possible for non-land owners to invest in water resources. Such changes potentially redefine the property relationships with Australian farm enterprises and might also initiate a set of unprecedented changes as to how farm owners organise their agricultural businesses, and manage their farm assets. Landowners now have access to a range of opportunities when managing two of the primary assets that contribute to agricultural production previously unavailable to them when water was associated with land titles. However, little research attempts to integrate the burgeoning literature on the impact of water markets with the broader rural geographical and sociological literatures addressing the structure of agricultural production in western economies. This combination has political relevance given the scale of public investment into upgrades of irrigation infrastructure currently taking place in Australia (particularly in Northern Victoria), the success and sustainability of which will be impacted by individuals' decisions concerning their farm businesses and land holdings.

In this paper, I propose a research approach intended to respond to the scarcity of research that specifically addresses the socio-economic organisation of farms and changes to the historic property regime and, in doing so, to show the important contribution that work conducted at the scale of the farm enterprise can make to discussions concerning the sustainability of irrigation districts and the efficacy of new governance structures for water. Broadly, I argue that the separation of land and water titles represents one of the most significant changes to the agricultural property regime since the State governments implemented land selection and closer settlement schemes in the late $19^{\text {th }}$ and early $20^{\text {th }}$ centuries, disrupting the dominant land tenure system at the time. Focusing on changes to the dominant property foundation of farms in the context of water management provides insights into a number of key themes in rural and water research. In particular, it contributes an additional and critical dimension to understanding the ways in which farmers integrate, resist and negotiate new governance structures for water and irrigation management, within their farms, comprising the farm business, the farm household, their land holdings and (now) water holdings.

In the next section, I briefly review the relevant changes to water ownership in Australia, before reviewing the literature concerning the socio-economic organisation of agriculture. In the final section, I present a research approach designed to develop better understandings of these water reforms at the local and land holder scales. 


\section{Literature review}

The research approach proposed here brings together several fields of enquiry that are not often integrated. It seeks to create a framework for the development of a more embodied understanding of the interaction between agricultural production, environmental governance structures and property rights. Australia, the jurisdiction under investigation here, is of particular interest due to the prevailing neoliberal reforms which have impacted the terms of trade under which agricultural producers operate. It is into this market-led agricultural system that environmental protection mechanisms are being introduced; many of which have implications for property rights and farmers' use of their land.

\subsection{Water reform in Australia}

Agricultural water consumption was driven by significant government investment in water storage and delivery infrastructure throughout much of the $20^{\text {th }}$ century. The sustainability of this approach began to be questioned during the 1970s and 1980s, and greater attention began to be directed toward remedying environmental impacts, including those associated with the overallocation of water resources [1]. To better allocate water resources between competing uses, a water market in which water licence holders were able to trade their entitlements on a temporary basis was introduced [2]. Subsequent modifications have removed many of the restrictions first applied, allowing water to be traded not only on a permanent basis, but also between irrigation districts and Australian states. Despite these developments, water ownership remained fundamentally connected to land.

Formal transition to full, legal separation of land and water titles began at the third Council of Australian Governments meeting, at which water resource policy was included on the agenda. Here, agreement was reached concerning the separation of water property rights from land titles [3]. Despite these initial moves in 1994, it would take more than a decade before all jurisdictions through which the Murray Darling River system passes had formally separated water access from land titles, and many issues concerning the status of entitlements were left unresolved.

The status of water entitlements was addressed in the 2004 intergovernmental agreement that produced the National Water Initiative (NWI) which is "Australia's blueprint for ongoing water reform by governments. Through it, governments across Australia have committed to a range of actions designed to achieve a nationally compatible market, regulatory and planning based system of managing water resources" (p. 4) [4]. In the case of water entitlements, under the NWI, the parties concerned agreed to a range of measures designed to provide greater consistency across jurisdictions and greater specificity and certainty for holders of entitlements ('Intergovernmental Agreement on a National Water Initiative', 2004). From this impetus, subsequent changes have been made to water policies and the rules and regulations governing water market behaviours. 
The rationale behind these changes was to continue to remove impediments to the efficient operation of the water market. However, once the decision has been made to submit environmental resources to an individualized property rights regime, there are profound implications for policy and legal systems [5]. Not only are the implications profound for national institutions and administrative systems, but such changes also impact on the structure of other socio-economic institutions embedded at smaller scales, such as individual farm enterprises.

Within the context of farm enterprises, farmers now had greater flexibility in how they managed and structured their agricultural business, opening up a range of new strategies to organise farm assets. The process of 'unbundling' provided farmers opportunities to liquidate their water rights, thus freeing up capital to invest in other aspects of their enterprise. Water could then be leased back from water holders. Farmers would have greater flexibility in terms of their borrowing arrangements. Prior to unbundling, mortgages could only be for approved for land purchases, now mortgages could be granted specifically for water shares. Farmers could better manage their water needs by adjusting the reliability and the timeliness of water delivery. Finally, farmers could purchase water, without needing the capital outlay to purchase land as well. [6]. More generally, then, water as a separate asset impacts farmers' lending arrangements, including their equity ratios, their property valuations, and the payment of rates to local governments [7]. The consequence of these changes for farmers is that they might chose to re-structure their farm enterprises in novel and beneficial ways. The discussion now turns to the nature of Australian agriculture and current understandings concerning the socio-economic organisation of farm enterprises.

\subsection{Australian agriculture in historical context}

Australian agricultural industries, like those in most developed nations, are dominated (more than 90\%) by businesses organised around a family unit [8]. Thus, attempts to understand the impact of new governance mechanisms for water and irrigation cannot be separated from current knowledge concerning the nature of family farming. Family farm ownership is an enduring characteristic of Western agriculture, despite repeated predictions that family farming, as a social institution, is under threat from globalisation and the corporatisation of agriculture [9], family farms seem to be extremely resilient and remain a vital, enduring aspect of the agricultural/rural landscape [10]. This acknowledgement has resulted in several calls for greater theoristaion of family farming $[11,12]$, and more nuanced accounts of how farms are structured; to date, this type of research remains scarce in the rural social science literature.

When the concept of the 'family farm' is situated within its historical context, 'family farming' in Australia seems to be a product of the Anglo-Saxon, social ideals promoted by early colonial governments: “...the original shape of agriculture in the Australian colonies was not dominated by the now ubiquitous family farm but by broad scale pastoral holdings by wealthy squatters" (p. 1) [13]. The 'squatters' adopted a large-scale, pastoral farming system that allowed them flexibility in production location across their landholdings (held via government lease) depending upon rainfall variation at the time. For the most 
part, then, water scarcity was overcome by stock mobility and a farming system that required little in the way of infrastructure [14]. During the 1870s and 1880s, government policy brought about the demise of this farming system as increased population and new political ideologies focussed on settling small-scale farmers and their families on the land. Writing about the Western Australian context, Tonts [15] argued that the governing authorities considered themselves to be "...the architect of a desired cultural landscape and social class" (p. 104). Enactment of the 'yeoman ideal' (i.e., freehold properties, family operated, cultivated) and policies of 'closer settlement' were seen as the way to create a prosperous, virtuous society. Such policies have since been discontinued, but there remains a strong familial element within Australian agriculture.

Since that time, the dominant property regime of Australian agriculture has remained largely unchallenged. The more recent changes made to land and water ownership represents one of the most significant legislative changes to impact agricultural production in Australia. Within this government initiated system of individual title, property rights and land-based assets are a central tenant, yet as will be discussed in the next section, these aspects have not always been strongly recognised by rural researchers interested in the theorisation of how farms are socially and economically constructed.

\subsection{The socio-economic organisation of farm enterprises}

The socio-economic organisation of farm enterprises, and the types of strategies, farmers use to respond to economic, social and political changes have been investigated by a number of rural researchers [10, 16-20], but there seems to have been few attempts to integrate this body of research with work concerning the impact of new governance structures for water. Yet, the theoretical and empirical insights developed since the 1980s seem to offer a useful framework for understanding the impact upon agricultural producers of changes to land holdings and water ownership.

Research attention directed toward the structure of farming recognises family farms as being uniquely shaped by the interaction between a business entity and a set of human relations within the associated household [20]. Johnsen [18] extended our understanding of the interconnections between the components comprising family farms by developing 'an actor- and context-sensitive approach' in which she recognised the roles of the farm property (the respective landholdings) and the local context in shaping (and constraining) farm owners' decisions. For example, in Johnsen's study area, following the New Zealand government's withdrawal of agricultural support mechanisms, the adjustment strategies available to farmers were influenced by the size and topography of their landholdings, as well as the presence of large-scale, off-farm employment options which were applicable to farmers' knowledge and skill sets. While other rural areas might offer similar opportunities, those available will still be marked by local contextual factors.

The wider macro-context also shapes the structure of farm businesses as farmers (and their advisors) work within the confines of legal and administrative systems. Two Australian based studies are important to this discussion. First, 
Pritchard et al. [21] argue that the family farm is undergoing transformations that are producing economic entities that are governed by a family unit, but are also utilising legal and financial structures that are used throughout the economy. The restriction of this study to one particular industry limits the direct application of their findings to other agricultural industries, thus as acknowledged by the authors, there is scope for further exploration of what the concept of family farming means in the context of the $21^{\text {st }}$ century, and for the concept to be explored in other industries and regions.

In the second study, McAllister and Geno [22] highlight the need for farm structures and asset ownership to be explored further from economic and social perspectives.

Further research is indicated on varieties of farm asset ownership (the means of production): for example, machinery might be separately owned or leased in a more complex legal arrangement and tied back to the overall farm ownership structure in a variety of interesting and presumably beneficial ways. While agricultural economics takes some cognisance of how these arrangements are changing, our interest would be wider than economic; these arrangements also have social implications for farm life (p. 188, emphasis added).

Acknowledgement of the ways in which farmers' land assets and the broader legal and economic structures influence the socio-economic organisation of farming should draw our attention to the implications for farm enterprises of changes in the dominant property regime and the possible economic and social functions of water ownership now that it has been unbundled from land. (It also has implications for the ways in which data are generated and this is taken into consideration in the research agenda proposed in the following section.)

As noted above, these changes impact the value of farm properties and the lending behaviour of farmers' financial institutions, providing a myriad new ways for farm owners to manage and re-structure their land and water holdings, which might result in novel combinations of land tenure, for example. The options available to farmers are further complicated by the specific rules and regulations governing water trade, water delivery and the range of water products available, as well as the administrative realities of the governance system. Examples from the Victorian context include farmers' capacity to 'carry over' water allocations from one irrigation season to the next as a risk management strategy; water delivery charges, many of which are tied to land titles; and limits regarding the quantum of water that can be applied to a given land parcel.

Consideration of this suite of strategies within the framework of farms as a three-way coalition between business, household and property highlights the ways in which farmers' choices about their water entitlements will be mediated by broader enterprise and household aspirations. Nevertheless, new decisions about water ownership can fundamentally alter the asset base of individual farms, which if adopted widely by irrigators might contribute toward new structures of agricultural production emerging in rural Australia. This was found to be the case in research that investigated the impact of macro-economic reform in New Zealand where Coombes and Campbell [23] reported that the "old mode 
of regulation" (p. 14) was being replaced by new forms of regulation and accumulation. In the context of Australian water reform, the extent to which new accumulation strategies involving water are being adopted in favour of more traditional forms of regulation and accumulation are poorly understood.

In sum then, using the lens of changed property rights - specifically the separation of land and water - new insights might be gained concerning the impact of these new governance structures and the ways in which farmers integrate them (or not) into their farm businesses and family lives.

\section{Proposed research agenda}

The intersection between the socio-economic organisation of farms and property rights for water has particular relevance for Australian water management. The second and third reviews of the National Water Initiative, specifically recognised adjustment issues associated with changed water management that might impact water users and their communities [24, 25]. However, in the 'Second Biennial Assessment of progress in implementation of the National Water Initiative' [24], the National Water Commission stated their concern about the "insufficient understanding of the processes and causes of structural adjustment and [the] paucity of data at the necessary spatial and temporal scales to enable effective monitoring of adjustment. ...the success of the overall national water reform process will ultimately depend on how well the adjustment process proceeds in irrigation-dependent communities" (p. 204). Despite the Commission's recommendation to address this information deficiency, the subsequent assessment in 2011 found that "there has been little progress in improving our understanding of the socioeconomic impacts of water reform. ...there remains a need for better data on, and analysis of, the socioeconomic impacts of changes in water availability" (p. 128) [25]. A range of research projects have since been commissioned to help address this knowledge gap and to build on the body of literature investigating water markets and water trading. This work has provided critical insight into farmers' participation in permanent and temporary markets for water [26-29], and farmers' decision making processes when selling water to the Australian government [30, 31]. Much of this work, though, utilises phone or mail-out survey methods (sometimes including a smaller number of interviews) or analysis of longitudinal water market data. It seems, then, that a useful complement to this body of knowledge would be in-depth qualitative studies conducted at the local and individual landholder scales.

In particular, work adopting a more holistic framework of the farm enterprise in which the farm is the unit of analysis, such as that developed by Johnsen, would contribute toward a fine-grained understanding of the importance of water reform from other drivers of change, such as farmers' attitudes toward land, superannuation plans, local land markets, the likelihood of intergenerational transfer of the farm business, and farmers' aspirations for their children. More nuanced accounts of how farmers negotiate these issues would complement the small amount of work already completed addressing some of these issues on an individual basis $[32,33]$. 
Disentangling the influence of water reform from other factors impacting trajectories for rural accumulation might be assisted through implementing the same research approach in dry land farming regions where significant changes to land ownership have not yet been implemented. The intention, here, is not to compare irrigation districts with dry land farming regions so as to make generalisations about the nature of adjustment to water reform that might be applicable to other areas; rather the objective is to be able to contextualise water reform within local peculiarities. This approach would also provide critical insight into the value of adjustment opportunities available to farmers in irrigation and dry land areas after a prolonged drought and extensive water reform. Prior to these events, Bjornlund and McKay [27] argued that irrigators had better adjustment opportunities available to them than their dry land counterparts. However, it seems that this argument remains empirically untested.

To achieve this research objective, application of Riley's [34] method of 'farm life histories' seems suitable. This adaptation of the oral history approach utilises a series of farm walks; a technique that recognises the importance of the 'place' of farming (that is the landholdings) and is, therefore, consistent with the components of family farms discussed above. Participation in farm walks deliberately includes the farm landscape in the data generation process and, operates as a visual prompt for farmer narratives, the purpose of which is to illuminate important stages and factors in the evolution of their farm enterprises. In relation to water ownership, viewing a farmer's irrigation infrastructure might initiate narratives concerning capital improvements made and how these were prompted or mediated by (or a combination of) policy changes, enterprise lifecycle characteristics or changes in the farmer's personal life, for example. Follow-up, semi-structured interviews can be used to extend the conversations initiated during this first research encounter. This approach also gives credence to the role of local histories and the geography of places in adjustment trajectories for farm owners. Such a consideration warrants an in-depth research approach in order to elicit the likely complex narratives of the interaction between farm owners and the places in which they live.

In sum, the point of departure for this research is the structure of farms, and the purpose is to understand the role of water reforms within this broader context. The knowledge gained will contribute toward debates concerning water policy, as well as the on-going sustainability of Australia's agricultural businesses.

\section{Conclusion}

Farms are spaces characterised by the interplay between business interests, a social unit and environmental resources. Theoretical and empirical work on family farming has investigated the myriad adjustment strategies available to farmers, primarily, in response to economic reform, but has not adequately explored farmers' responses to the disruption of property relations upon which their agricultural production and livelihood is based. Thus, this paper has reiterated Brookfield's [11] call for increased attention to be given to the socio- 
economic organisation of farming, but to do so through the lens of property rights for water which has contemporary significance for Australian agriculture, and other nations facing the challenges of constructing effective governance structures for water management and irrigation areas.

A research approach has been presented to help address an identified research gap in rural social science and to contribute toward an information deficit consistent with the needs of Australian national water policy. It has argued that narrative accounts of the socio-economic organisation of family farming will provide more fine-grained understandings of the role water ownership has in Australian farm enterprises, now that water rights can be bought and sold independently from land title. These new insights will usefully complement the existing body of knowledge concerning the impact of water markets.

\section{References}

[1] Tisdell, J., Ward, J. and Grudzinski, T., The development of water reform in Australia, in Technical Report, Cooperative Research Centre for Catchment Hydrology: Canberra, 2002.

[2] Randall, A., Property entitlements and pricing policies for a maturing water economy. The Australian Journal of Agricultural Economics, 25(3), pp. 195-220, 1981.

[3] Council of Australian Governments, Communique, Attachment A - Water resource policy. Meeting of COAG in Hobart 25 February, 1994. Online. http://archive.coag.gov.au/coag_meeting_outcomes/1994-02-25/docs/ attachment_a.cfm

[4] National Water Commission, Water reform in Australia, National Water Commission: Canberra, 2007.

[5] McHarg, A., Barton, B., et al. Property and the law in energy and natural resources (Chapter 1). Property and the law in energy and natural resources, ed. A. McHarg, B. Barton et al. Oxford University Press: Oxford. pp. 1-16, 2012.

[6] Barlow, D. and Coates, H., Unbundling unbundling. Law Insitute Journal, 82(6), pp. 56-58, 2008.

[7] Bjornlund, H. and O'Callaghan, B., Property implications of the separation of land and water rights. Pacific Rim Property Research Journal, 10(1), pp. 54-78, 2004.

[8] Productivity Commission, Trends in Australian agriculture. Research Paper, Productivity Commission: Canberra, 2005.

[9] Lawrence, G., Capitalism and the countryside: The rural crisis in Australia, Sydney: Pluto Press, 1987.

[10] Lobley, M. and Potter, C., Agricultural change and restructuring: Recent evidence from a survey of agricultural households in England. Journal of Rural Studies, 20(4), pp. 499-510, 2004.

[11] Brookfield, H., Family farms are still around: Time to invert the old agraian questions, Geography Compass, 2(1), pp. 108-126, 2008. 
[12] Moran, W., Blunden, G. and Greenwood, J., The role of family farming in agrarian change, Progress in Human Geography, 17(1), pp. 22-42, 1993.

[13] Botterill, L., Policy approaches to farm exit: Some factors influencing the efficacy of Commonwealth programs. Bureau of Rural Sciences: Canberra, 2000.

[14] Harris, E., State administration versus private innovation: The evolution of property rights to water in Victoria, Australia (Chapter 4). The evolution of markets for water: Theory and practice in Australia, ed. J. Bennett, Edward Elgar Publishing Limited: Cheltenham, UK, pp. 38-55, 2005.

[15] Tonts, M., State policy and the yeoman ideal: Agricultural development in Western Australia, 1890-1914. Landscape Research, 27(1), pp. 103-115, 2002.

[16] Smithers, J. and Johnson, P. The dynamics of family farming in North Huron County, Ontario. Part I: Development trajectories. The Canadian Geographer, 48(2), pp. 191-208, 2004.

[17] Johnsen, S., The redefinition of family farming: Agricultural restructuring and farm adjustment in Waihemo, New Zealand. Journal of Rural Studies, 20(4), pp. 419-432, 2004.

[18] Johnsen, S., Contingency revealed: New Zealand farmers' experiences of agricultural restructuring. Sociologia Ruralis, 43(2), pp. 129-153, 2003.

[19] Johnsen, S., Agricultural restructuring and response: Inter-relationships between farm adjustment strategies in Waihemo, 1984-1997. New Zealand Geographer, 55(1), pp. 25-34, 1999.

[20] Gasson, R. and Errington, A., The farm family business. Oxon: CAB International, 1993.

[21] Pritchard, B., Burch, D. and Lawrence, G., Neither 'family' nor 'corporate' farming: Australian tomato growers as farm family entrepreneurs. Journal of Rural Studies, 23(1), pp. 75-87, 2007.

[22] McAllister, J. and Geno, B., Australian farm inheritance: New patterns of legal structure in property rights and landholding. Rural Society, 14(2), pp. 178-192, 2004.

[23] Coombes, B. and Campbell, H., Pluriactivity in (and beyond?) a regulationist crisis. New Zealand Geographer, 52(2), pp. 11-17, 1996.

[24] National Water Commission, Australian water reform 2009: Second biennial assessment of progress in implementation of the National Water Initiative, National Water Commission: Canberra, 2009.

[25] National Water Commission, The National Water Initiative: Securing Australia's water future, 2011 assessment, National Water Commission: Canberra, 2011.

[26] Wheeler, S., et al. The changing profile of water traders in the GoulburnMurray Irrigation District, Australia. Agricultural Water Management, 97(9), pp. 1333-1343, 2010.

[27] Bjornlund, H. and McKay, J., Do permanent water markets facilitate farm adjustment and structural change within irrigation communities? Rural Society, 9(3), pp. 555-571, 1999. 
[28] Wheeler, S., Bjornlund, H., et al. Who trades water allocations? Evidence of the characteristics of early adopters in the Goulburn-Murray Irrigation District, Australia 1998-1999. Agricultural Economics, 40(6), pp. 631-643, 2009.

[29] Bjornlund, H., The socio-economic strcuture of irrigation communities: Water markets and the structural adjustment process. Rural Society, 12(2), pp. 123-147, 2002.

[30] Cheeseman, J. and Wheeler, S., Survey of water entitlement sellers under the Restoring the Balance in the Murray-Darling Basin Program: Final report prepared for the Department of Sustainability, Environment, Water, Population and Communities. Marsden Jacob Associates Pty Ltd: Melbourne, 2012.

[31] Wheeler, S., Zuo, A., et al. Selling the farm silver? Understanding water sales to the Australian Government. Environmental and Resource Economics, 52(1), pp. 133-154, 2012.

[32] Bjornlund, H. and Rossini, P., Climate change, water scarcity and water markets: Implications for farmers' wealth and farm succession. Proc. of the 16th Pacific Rim Real Estate Society Conference. Wellington, New Zealand, 2010. Online. http://www.prres.net/index.htm?http:// www.prres.net/Proceedings/2010proceedings.asp

[33] Wheeler, S., Bjornlund, H., et al. Handing down the farm: The increasing uncertainty of irrigated farm succession in Australia. Journal of Rural Studies, 28(3), pp. 266-275, 2012.

[34] Riley, M., Emplacing the research encounter: Exploring farm life histories. Qualitative Inquiry, 16(8), pp. 651-662, 2010. 